an increased periodicity (8 issues per year)

- supplements devoted to specific symposia

\section{- indexed in Current Contents}

\begin{tabular}{lll}
\cline { 1 - 1 } Editors & Co-Editors & Deputy Editors \\
C Ballus & M Maj & P Boyer \\
Barcelona, Spain & Naples, Italy & Paris, France \\
JD Guelfi & CB Pull & Y Lecrubier \\
Paris, France & Luxembourg & Paris, France \\
H Heimann & M Ackenheil & \\
Tübingen, Germany & Munich, Germany & \\
R Murray & P Bech & \\
London, United Kingdom & Copenhagen, Denmark &
\end{tabular}

Indexed in

Biological

Abstracts/Biosis,

CNRS/Pascal, Current

Contents/Clinical

Medicine and Social $\&$

Behavioural Sciences,

Excerpta Medica/EMbase,

Psychological Abstracts,

Research Alert, SciSearch
Since 1991, European Psychiatry has been the official journal of the Association of European Psychiatrists (AEP).

European Psychiatry presents the results of original research relative to those numerous diverse fields currently of interest to psychiatrists: psychopathology, nosography, chemotherapy, psychotherapy, clinical methodology, biological disorders and mental pathology, psychophysiology, neuropsychophysiology, relative to therapeutics, clinical and basic research as well as animal behaviour.

This wide scope is aimed at encouraging the exchange of ideas and research within Europe and establishing within the international psychiatric community an improved level of scientific communication.

European Psychiatry endeavours to publish not only high scientific level original articles, short communications, editorials, letters to the editor but also AEP newsletters, book reviews, information on new regulations in Europe and a conference calendar.

\section{Submission of manuscripts}

should be made to one of the Editors indicated above. Addresses of the Editors and Instructions to Authors are available upon request from the secretariat (European Psychiatry, Hôpital de la Salpêtrière, Pavillon Clérambault, 47, bd de l'Hôpital, 75651 Paris cedex 13, France. Fax no: 33 (1) 458528 00)

EUROPEAN PSYCHIATRY - 1996 - Volume 11 in 8 issues - ISSN 0924-9338

Please, send to:

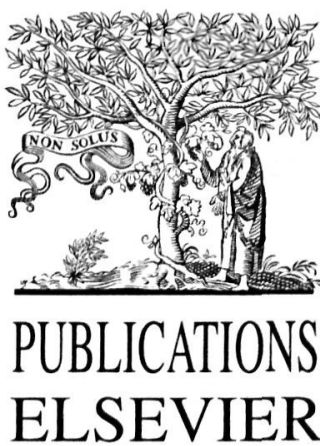

A division of ÉDITIONS SCIENTIFIQUES ET MÉDICALES ELSEVIER SAS 141, rue de Javel 75747 Paris Cedex 15, France

$Q \wedge$ member of the Reed Elsevier Mediral group

in North America:

Elsevier Science inc.

655 Avenue of the Americas

New York, NY 10010, USA
Please,

$\square$ enter my 1996 subscription to European Psychiatry

France: $1885 \mathrm{FF}$ - EU (with VAT registration no ) and rest of the world: $2115 \mathrm{FF}$ EU (individuals): $2159 \mathrm{FF}$ - North, Central and South America: 413 US \$

Students (copy of the student card requested) France: 1131 FF - Rest of the world: 1296 FF

All price include postage and handling

$\square$ send me a free sample copy

$\square$ find my check enclosed payable to ESME

$\square$ debit my credit card (CB, MasterCard or Visa)

No $\sqcup \perp \perp|\perp| \perp|\perp||| \perp|\perp| \perp$ Expires $\sqcup \perp|\perp|$ Signature:

$\square$ send me an invoice

A special rate is available to the members of the Association of European Psychiatrists 


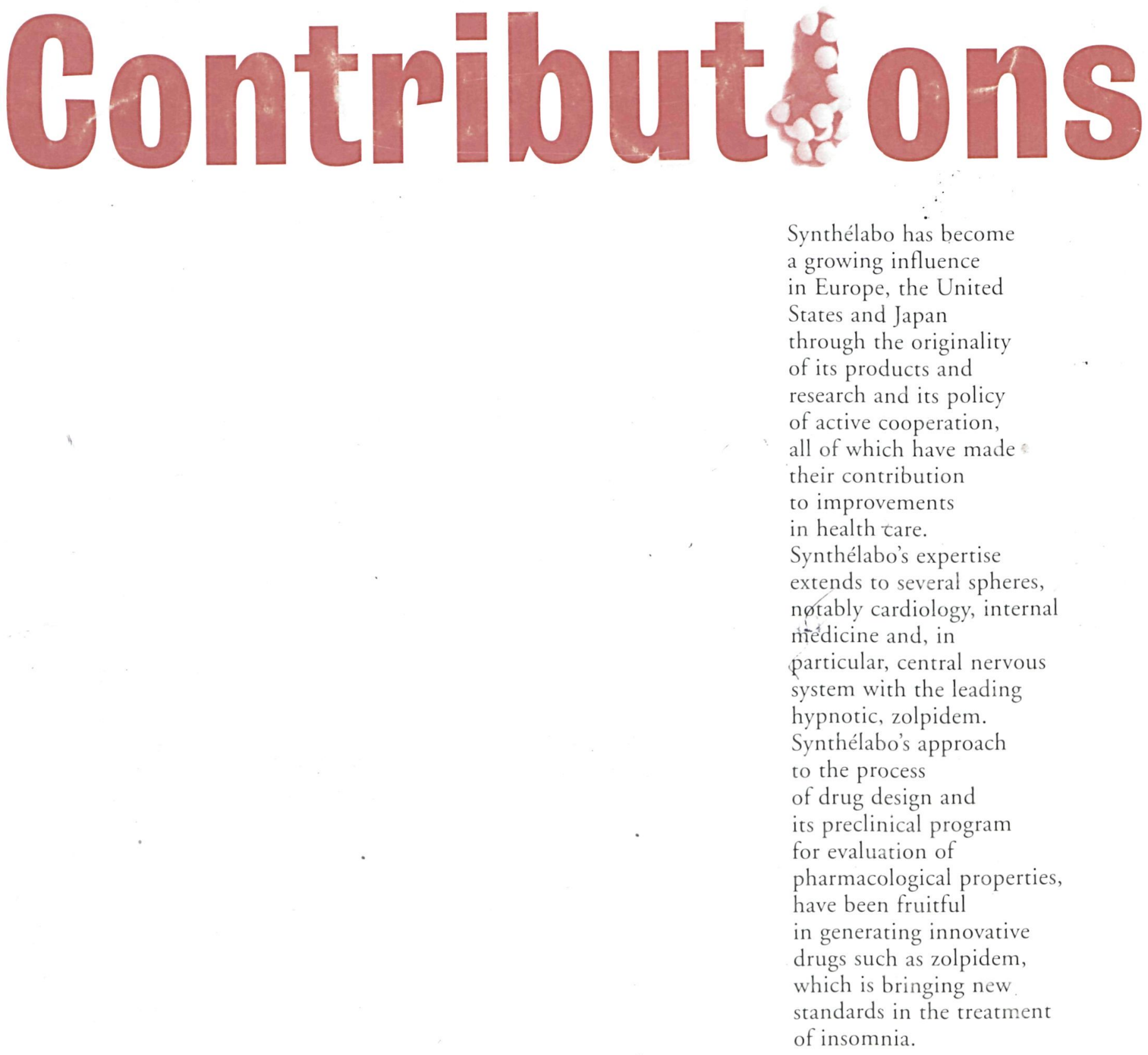

